\title{
Comparison of Effects of Administration of Oral or Topical Boron on Wound Healing and Oxidative Stress in Rats
}

\author{
Meral KONCA ${ }^{1}$, Musa KORKMAZ2* \\ 1 Asya Veterinary Clinic, Afyonkarahisar \\ 2 Afyon Kocatepe University, Faculty of Veterinary Medicine, Department of Surgery, Afyonkarahisar
}

\begin{abstract}
The purpose of this study was to determine the effects of boron on wound healing and further evaluate some antioxidant and oxidant characteristics. A total of 32 adult male Wistar rats were divided into four groups; control group, local boron (LB) group, oral boron (OB) group, and oral+local boron (OLB) group. Under general anesthesia, a circular full-thickness skin defect with a diameter of $1.5 \mathrm{~cm}$ was created on the dorsal region of the rats. Boron $(10 \mathrm{mg} / \mathrm{kg})$ was administered per oral in OB group and $3 \%$ boric acid was administered topically in LB group, and $10 \mathrm{mg} / \mathrm{kg}$ boron was administered per oral and 3\% boric acid was applied topically in OLB group. Control group did not receive any medication. In histopathological examination, re-epithelialization, granulation tissue formation, collagen formation, inflammatory cell formation, and neovascularization were found to be more superior in LB and OLB groups as compared to the control and OB groups. Blood and wound tissue MDA levels in OB and OLB groups were lower with respect to the control and LB groups $(p<0.05)$. In conclusion, oral administration of boron in addition to topical treatment contributes the wound healing due to the antioxidant property of boron in wound healing process.
\end{abstract}

Keywords: Antioxidant, boron, malondialdehyde, rat, wound healing

\section{$* * *$ \\ Ratlarda Oral veya Topikal Olarak Uygulanan Borun Yara İyileşmesi ve Oksidatif Stres Üzerine Etkilerinin Karşılaştırılması}

ÖZ

Bu çalışmanın amacı, borun yara iyileşmesi ve bazı antioksidan ve oksidan parametreler üzerine olan etkisinin belirlenmesidir. Çalışmada, toplam 32 adet erişkin erkek Wistar ratı, kontrol grubu, lokal bor (LB) grubu, oral bor (OB) grubu ve oral+lokal bor (OLB) grubu olmak üzere ratgele dört gruba ayrıldı. Genel anestezi altında, ratların sırt bölgesinde $1,5 \mathrm{~cm}$ çapında dairesel tam kat bir deri defekti oluşturuldu. OB grubunda bulunan ratlara oral olarak $10 \mathrm{mg} / \mathrm{kg}$ bor, LB grubunda bulunan ratlara topikal \% 3'lük borik asit, OLB grubunda bulunan ratlara oral $10 \mathrm{mg} / \mathrm{kg}$ bor ile birlikte topikal olarak \% 3’lük borik asit uyguland. Kontrol grubuna ise herhangi bir ilaç uygulanmadı. Histopatalojik inceleme için yara dokusu örnekleri alındı. Histopatolojik olarak; repitelizasyon, granulasyon dokusu oluşumu, kollagen formasyonu, yangısal hücre oluşumu ve neovaskülarizasyonun LB ve OLB gruplarında kontrol ve OB grubuna göre daha iyi olduğu belirlendi. OB ve OLB gruplarında kan ve yara dokusu MDA düzeylerinin kontrol ve LB grubuna göre düşük olduğu belirlendi $(\mathrm{p}<0,05)$. Sonuç olarak; yara sağaltımında, lokal olarak borik asit kullanıma ek olarak antioksidan özelliklerinden dolayı oral bor kullanımının yara iyileşmesine katkı sağladığ1 söylenebilir

Anahtar Kelimeler: Antioksidan, bor, malondialdehit, rat, yara iyileşmesi

To cite this article: Konca M. Korkmaz. M. Comparison of Effects of Administration of Oral or Topical Boron on Wound Healing and Oxidative Stress in Rats. Kocatepe Vet J. (2020) 13(1):11-18.

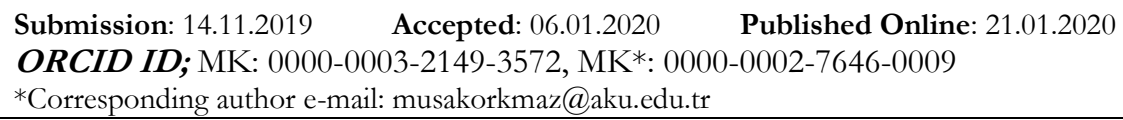




\section{INTRODUCTION}

Wound healing is a complex physiological process involving interrelated stages and affected by many factors. To understand the fundamental principles of wound healing, it is necessary to know the physiology of the process of wound healing including the stages such as hemostasis, inflammation, proliferation, and remodeling (Keast and Orsted 1998, Beckert et al. 2007, Singh et al. 2017). The basic approach for ensuring wound healing in a shorter period of time and ideal scar formation is affected by inflammatory cells, platelets, and some mediators that play a key role in this process. Besides the factors such as collagen synthesis, angiogenesis and extracellular matrix formation are also effective in wound healing (Werner and Grose 2003, Kapan et al. 2008, Özler et al. 2010).

Boron is an essential element and it is generally used in industrial, agricultural and cosmetic applications as well as in the field of healthcare (Murray 1998). Boron has very important role in mineral and hormone metabolism, bone development, antioxidant defense system, wound healing, energy metabolism, and immune system (Kuru and Yarat, 2018). It is an element essential for maintaining the balance and amount of magnesium, phosphorus, and calcium, exclusively in the bone (Wilson and Ruszler 1998). In various studies, it has been demonstrated that boron has antioxidant (Ince et al. 2010, Uçkun 2013, Coban et al. 2015), hepatoprotective (Ince et al. 2012), and anti-genotoxic effects ((Ince et al. 2014). Boron is a wound healing material, and it has been reported that $3 \%$ boric acid solution can cure deep wounds (Blech et al. 1990a). Nowadays, borates are used in wound treatment at very low concentrations. Although action mechanism of boron in wound healing is not completely known, however some experiments have revealed that it may be associated with protein, collagen and proteoglycan synthesis (Benderdour et al. 1998, Nzietchueng et al. 2002). Boron regulates the production of the extracellular matrix that plays a significant role in providing protein, collagen, and proteoglycans to the environment in wound healing. Boron hydrogel formulation has also been shown to yield successful results in the healing of burns. This borate formulation is thought to positively affect the healing of burns through complex mechanisms such as stimulation of cell migration, immune response, vascularization and growth factor expression (Demirci et al. 2015).

The purpose of this study was to determine the effect of oral or topical administered borax decahydrate on experimentally induced wound healing and to evaluate some antioxidant and oxidant parameters in wound tissue and blood.

\section{MATERIAL and METHOD}

The study was approved by the Local Animal Ethical Committee (07.09.2019/117). A total of 32 adult male Wistar rats having weight between 200-250 g were randomly divided into four groups as control group $(\mathrm{n}=8)$, local boron (LB) group $(\mathrm{n}=8)$, oral boron (OB) group, and oral+local boron (OLB) group $(\mathrm{n}=8)$. Animals were fed with standard rat feed and water ad libitum. Furthermore, boron level of drinking water of all rats was determined by ICP-MS (7700x, Agilent, USA) (Gultepe et al. 2018).

\section{Surgical procedure}

The intramuscular route of $10 \mathrm{mg} / \mathrm{kg}$ xylazine (Alfazine $2 \%{ }^{\circledR}$, Egevet) and $100 \mathrm{mg} / \mathrm{kg}$ ketamine hydrochloride (Alfamine 10\% ${ }^{\circledR}$, Egevet) were used for general anesthesia.

The hair on the dorsal region of the rats were shaved by a razor blade without damaging the skin and the dorsal region was cleaned with povidone-iodine. Two circular full-thickness skin defects with a diameter of $1.5 \mathrm{~cm}$ were performed on the dorsal region of the rats under general anesthesia. After performing the skin defect, the wounds were cleaned only with physiological saline solution. Control group did not receive any medication during the study period. 10 $\mathrm{mg} / \mathrm{kg}$ borax decahydrate $\left(\mathrm{Na}_{2} \mathrm{~B}_{4} \mathrm{O}_{7} \cdot 10 \mathrm{H}_{2} \mathrm{O}\right.$, Eti Mine Institute, Kırka, Eskişehir) was administered by oral gavage to the rats in $\mathrm{OB}$ group, $3 \%$ boric acid $\left(\mathrm{H}_{3} \mathrm{BO}_{3}\right.$, Eti Mine Institute, Kırka, Eskişehir) was administered topically to the rats in LB group, 10 $\mathrm{mg} / \mathrm{kg}$ borax decahydrate was administered orally and $3 \%$ boric acid was administered topically by spraying to the rats in the oral+local boron group. The course of wound healing was monitored by plotting wound sizes on acetate paper on days $0,1,3,5,7,9,11,13$, $15,17,19$ and 21.

\section{Collection of blood samples}

The whole blood samples in EDTA were used for the measurement of concentrations of MDA and GSH, whereas SOD and CAT were measured in the rest of the samples following the separation for erythrocyte preparation.

\section{Preparation of erythrocytes and wound tissue homogenate}

Erythrocyte lysate was prepared by the method described by Winterbourn et al. (1975). The lysate was stored at $4^{\circ} \mathrm{C}$ until analysis within three days.

Under general anaesthesia, $1 \mathrm{~g}$ of skin tissues were removed from wound sites. Wound tissue homogenate was prepared by the method described by Bolcal et al. (2007). Tissue supernatants were stored in a deep freezer at $-70^{\circ} \mathrm{C}$ until analysed. 


\section{Measurement of Oxidant and Antioxidant Enzyme Levels}

The levels of MDA in blood and tissue homogenates were assayed by Draper and Hadley (1990) and Ohkawa et al. (1979) respectively. Both blood and tissue homogenates GSH concentrations were determined by using a spectrophotometer (Shimadzu 1601 UV-VIS, Tokyo, Japan) (Beutler et al. 1963). The antioxidant enzyme activity of SOD was measured as described by Sun et al. (1988). CAT activity in erythrocyte lysate and tissue homogenate was measured by the method described by Luck (1955) and Aebi (1983).

\section{Measurement of Hemoglobin ( $\mathrm{Hb})$ and Protein Concentrations}

The concentration of $\mathrm{Hb}$ was determined by the method according to Drabkin and Austin (1935) and tissue protein content was measured according to the colorimetric method of Lowry et al. (1951).

\section{Histopathological Examination}

After obtaining blood and wound tissue samples, the animals were euthanized by administering a high dose of anaesthetic. Skin samples were placed in 10\% formaldehyde for histopathological examination. They were processed and embedded in paraffin blocks and were cut into $5 \mu \mathrm{m}$ thickness with a microtome. After deparaffinisation, these sections were stained with the hematoxylin-eosin and evaluated according to the wound healing scale (Table 1).

\section{Statistical Analysis}

The ANOVA test was performed to determine the differences between the concentrations of MDA, GSH, SOD and CAT in blood samples and wound tissue. The wound healing scores between the groups were evaluated by the Kruskal-Wallis test. Data were presented as mean \pm standard deviation and $\mathrm{p}<0.05$ and 0.01 were considered statistically significant.

\section{RESULTS}

The level of boron supplemented in drinking water of rats was $0.324 \mathrm{ppb}$. Histopathologically, when all wound scores were taken into consideration, Reepithelialization, granulation tissue formation, collagen formation, inflammatory cell formation, and neovascularization were higher in LB and OLB groups. Although no ulcer formation was observed in all animals in OLB group $(p<0.05)$, ulcer formation was lower in LB group than control and OB groups (Table 2) (Figure 1). Reepithelization, granulation tissue formation, inflammatory cell formation, and neovascularization scores were highest particularly in OLB group. The reepithelization score was significantly higher in LB and OLB groups than control and $O B$ groups $(\mathrm{p}<0.05)$. There was a statistically significant difference between the control and $\mathrm{LB}, \mathrm{OB}$ and $\mathrm{OLB}$ groups in terms of granulation tissue formation $(p<0.05)$. While the least collagen formation was observed in the control group, the highest level of collagen formation was noted in LB group. Collagen formation was significantly higher in the $\mathrm{LB}, \mathrm{OB}$ and OLB groups compared to the control group $(p<0.05)$. The presence of inflammatory cells and neovascularization score were significantly higher in LB, OB and OLB groups than control group $(\mathrm{p}<0.05)$.

When the wound surface areas were compared, the wound areas shrank more rapidly in LB and OLB groups when compared with the control group. It was determined that the wounds shrank more rapidly in LB group and more than half of the wound areas shrank on the 7th day (Table 3). A statistically significant difference was observed between LB group and the control and OLB groups in terms of the wound area on the 7 th day $(\mathrm{p}<0.05)$. In the intergroup comparison, the wound areas were observed to be significantly smaller on days 7, 9,11,13,17, 19 and 21 in the $\mathrm{LB}, \mathrm{OB}$ and OLB groups than control group $(\mathrm{p}<0.05)$.

Changes in GSH, MDA, SOD and CAT levels in all groups are given in Table 4. While the blood GSH level was determined to be higher in $\mathrm{OB}$ group compared to other groups, the lowest blood GSH level was observed in the control group. Changes in the blood GSH level were not statistically significant between the groups $(\mathrm{p}>0.05)$. The blood and tissue MDA levels were lower in OB and LB groups than control and OLB groups. The blood MDA levels in the $\mathrm{OB}$ group were significantly lower than those in the OB and OLB groups $(p<0.05)$. Especially the blood SOD level in LB group had more concentration as compared to other groups. A statistically significant difference was determined between the control and LB groups in terms of the blood SOD level $(p<0.05)$. While the highest blood CAT level was found in the LB group, there was a statistically significant difference in blood CAT levels between the control and LB groups $(p<0.05)$.

The wound tissue GSH, MDA, SOD and CAT levels in the control, $\mathrm{LB}, \mathrm{OB}$ and OLB groups are given in Table 5. While the highest wound tissue GSH level was determined in the $\mathrm{OB}$ group, no statistically significant difference was determined between the groups in terms of wound tissue GSH levels $(p>0.05)$. Wound tissue MDA levels were significantly lower in the OB and OLB groups in comparison with the control and LB groups $(\mathrm{p}<0.05)$. There was a statistically significant difference between the control and LB group and between the control group and OLB group in terms of wound tissue SOD levels $(p<0.05)$. There was no statistically significant difference between the groups in terms of wound tissue catalase levels $(\mathrm{p}>0.05)$. 


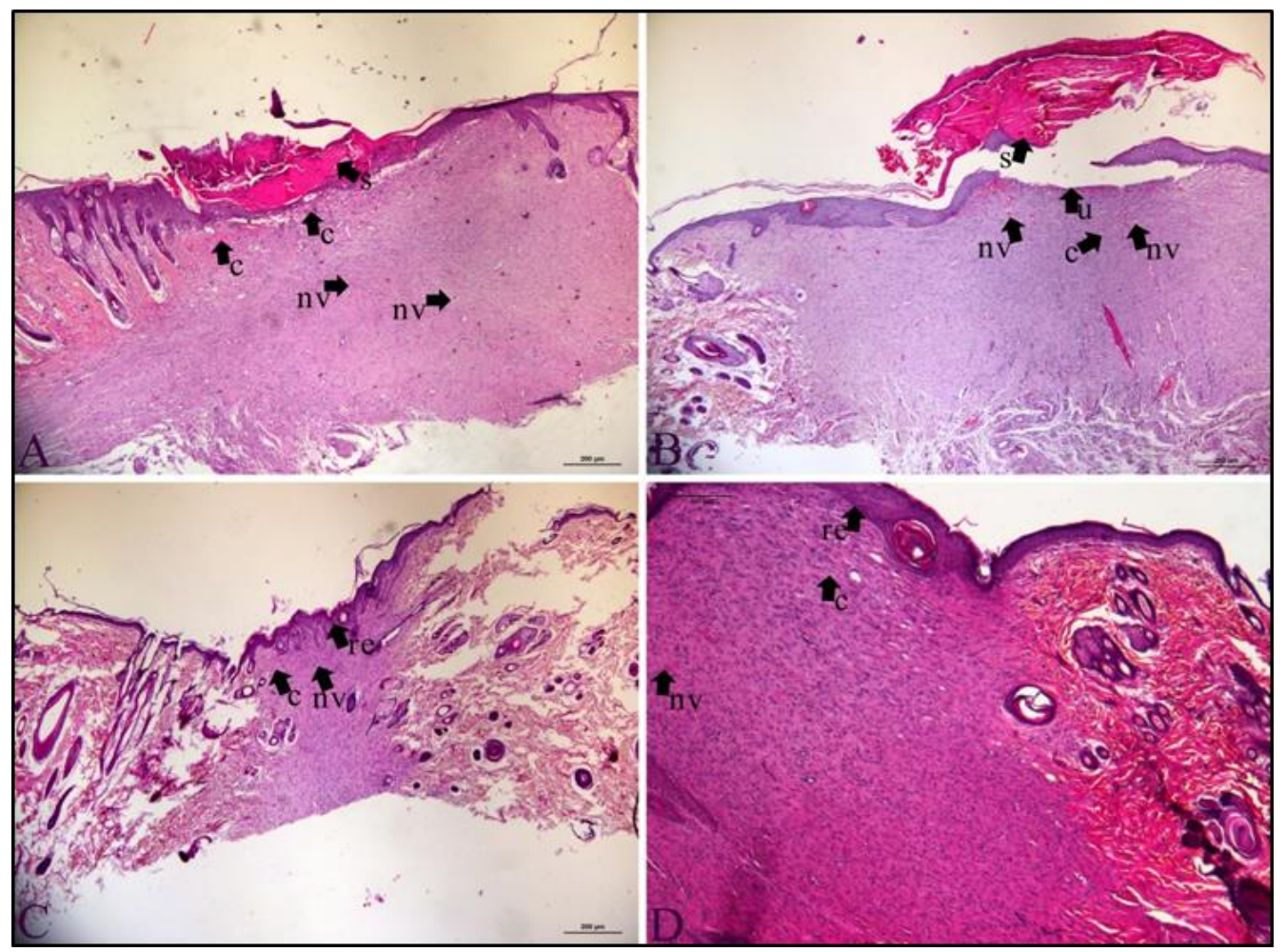

Figure 1. Histopathological sections in control (A), oral boron (B), local boron (C) and oral+local boron groups (H\&E staining)

(c: collagen, s: scab, nv: neovascularization, u: ulcer, re: reepithelization)

Table 1. Wound healing score evaluation criteria

\begin{tabular}{ccccccc}
\hline Score & Reepithelization & $\begin{array}{c}\text { Granulation } \\
\text { tissue }\end{array}$ & $\begin{array}{c}\text { Collagen } \\
\text { accumulation }\end{array}$ & $\begin{array}{c}\text { Presence of } \\
\text { inflammatory } \\
\text { cells }\end{array}$ & Neovascularization & Ulcer \\
\hline $\mathbf{0}$ & No & $\begin{array}{c}\text { No or } \\
\text { immature }\end{array}$ & No & No & No & $\begin{array}{c}\text { Wide, deep } \\
\text { ulcer, } \\
\text { abscess }\end{array}$ \\
$\mathbf{1}$ & Partial & Little & Little & Little & $\begin{array}{c}\text { Less than } 5 \text { blood } \\
\text { vessels } \\
\text { Wide ulcer }\end{array}$ \\
$\mathbf{2}$ & $\begin{array}{c}\text { Completed but thin } \\
\text { or immature }\end{array}$ & $\begin{array}{c}\text { Moderate } \\
\text { maturation }\end{array}$ & Moderate & Moderate & 6-10 blood vessels & $\begin{array}{c}\text { None or } \\
\text { very small }\end{array}$ \\
$\mathbf{3}$ & $\begin{array}{c}\text { Completed and } \\
\text { mature }\end{array}$ & Mature & Abundant & Abundant & $\begin{array}{c}\text { More than } 10 \text { blood } \\
\text { vessels }\end{array}$ & None \\
\hline
\end{tabular}

Table 2. Wound healing scores in the control $(\mathrm{n}=8)$, local boron $(\mathrm{LB})(\mathrm{n}=8)$, oral boron $(\mathrm{OB})(\mathrm{n}=8)$ and oral + local boron $(\mathrm{OLB})(\mathrm{n}=8)$ groups (mean $\pm \mathrm{SD})$

\begin{tabular}{ccccccc}
\hline Reepithelization & $\begin{array}{c}\text { Granulation } \\
\text { tissue }\end{array}$ & $\begin{array}{c}\text { Collagen } \\
\text { accumulation }\end{array}$ & $\begin{array}{c}\text { Presence of } \\
\text { inflammatory } \\
\text { cells }\end{array}$ & Neovascularization & Ulcer \\
\hline $\begin{array}{c}\text { Control } \\
\text { group } \\
\mathbf{~ L B}\end{array}$ & $0,37+0,5^{\mathrm{b}}$ & $0,37+0,5^{\mathrm{d}}$ & $0,50+0,5^{\mathrm{b}}$ & $0,62+0,5^{\mathrm{c}}$ & $0,62+0,5^{\mathrm{c}}$ & $0,62+0,5^{\mathrm{a}}$ \\
$\begin{array}{c}\text { group } \\
\text { OB }\end{array}$ & $1,61+0,5^{\mathrm{a}}$ & $1,62+0,5^{\mathrm{ab}}$ & $1,50+0,5^{\mathrm{a}}$ & $1,5+0,5^{\mathrm{ab}}$ & $1,62+0,5^{\mathrm{b}}$ & $\begin{array}{c}0,12+0,3^{\mathrm{a}} \\
\mathrm{b}\end{array}$ \\
$\begin{array}{c}\text { group } \\
\text { OLB } \\
\text { group }\end{array}$ & $0,5+0,5^{\mathrm{b}}$ & $1,37+0,5^{\mathrm{c}}$ & $1,25+0,4^{\mathrm{a}}$ & $1,25+0,4^{\mathrm{b}}$ & $1,12+0,6^{\mathrm{b}}$ & $\begin{array}{c}0,37+0,5^{\mathrm{a}} \\
\mathrm{b}\end{array}$ \\
\hline $\boldsymbol{P}$ & $2,0+0^{\mathrm{a}}$ & $2,0+0^{\mathrm{a}}$ & $1,0+0^{\mathrm{ab}}$ & $2,0+0^{\mathrm{a}}$ & $2,0+0^{\mathrm{a}}$ & $0^{\mathrm{c}}$ \\
\hline
\end{tabular}

$\overline{\mathrm{abc}}$ Different letters in same column indicate significant differences $(\mathrm{p}<0.05)$ 
Table 3. Changes of wound surface areas in the control $(\mathrm{n}=8)$, local boron $(\mathrm{LB})(\mathrm{n}=8)$, oral boron $(\mathrm{OB})(\mathrm{n}=8)$ and oral + local boron $(\mathrm{OLB})(\mathrm{n}=8)$ groups at measurement days (mean $\pm \mathrm{SD})$

\begin{tabular}{ccccc}
\hline Days & Control group & LB group & OB group & OLB group \\
\hline $\mathbf{0}$ & $1,77 \pm 0$ & $1,77 \pm 0$ & $1,77 \pm 0$ & $1,77 \pm 0$ \\
$\mathbf{1}$ & $1,77 \pm 0$ & $1,68 \pm 0,12$ & $1,74 \pm 0,08$ & $1,71 \pm 0,11$ \\
$\mathbf{3}$ & $1,68 \pm 0,12$ & $1,41 \pm 022$ & $1,55 \pm 0,27$ & $1,65 \pm 0,17$ \\
$\mathbf{5}$ & $1,44 \pm 0,22$ & $1,22 \pm 0,3$ & $1,32 \pm 0,28$ & $1,41 \pm 0,25$ \\
$\mathbf{7}$ & $1,11 \pm 0,35^{\mathrm{a}}$ & $0,72 \pm 09^{\mathrm{b}}$ & $1,07 \pm 0,19^{\mathrm{ab}}$ & $1,12 \pm 0,21^{\mathrm{a}}$ \\
$\mathbf{9}$ & $0,72 \pm 0,30^{\mathrm{a}}$ & $0,35 \pm 0,23^{\mathrm{b}}$ & $0,59 \pm 0,17^{\mathrm{ab}}$ & $0,70 \pm 0,3^{\mathrm{ab}}$ \\
$\mathbf{1 1}$ & $0,39 \pm 0,12^{\mathrm{a}}$ & $0,18 \pm 0,08^{\mathrm{b}}$ & $0,33 \pm 0,11^{\mathrm{ab}}$ & $0,36 \pm 0,15^{\mathrm{a}}$ \\
$\mathbf{1 3}$ & $0,31 \pm 0,09^{\mathrm{a}}$ & $0,16 \pm 0,07^{\mathrm{b}}$ & $0,20 \pm 0,07^{\mathrm{b}}$ & $0,24 \pm 0,05^{\mathrm{ab}}$ \\
$\mathbf{1 5}$ & $0,16 \pm 0,07$ & $0,10 \pm 0,05$ & $0,12 \pm 0,04$ & $0,13 \pm 0,03$ \\
$\mathbf{1 7}$ & $0,19 \pm 0,10^{\mathrm{a}}$ & $0,08 \pm 0,03^{\mathrm{b}}$ & $0,09 \pm 0,04^{\mathrm{b}}$ & $0,11 \pm 0,04^{\mathrm{ab}}$ \\
$\mathbf{1 9}$ & $0,14 \pm 0,04^{\mathrm{a}}$ & $0,02 \pm 0,02^{\mathrm{c}}$ & $0,08 \pm 0,05^{\mathrm{b}}$ & $0,05 \pm 0,03^{\mathrm{cb}}$ \\
$\mathbf{2 1}$ & $0,06 \pm 0,03^{\mathrm{a}}$ & $0,003 \pm 0,004^{\mathrm{c}}$ & $0,03 \pm 0,03^{\mathrm{b}}$ & $0,008 \pm 0,01^{\mathrm{cb}}$ \\
\hline
\end{tabular}

abc Different letters in same line indicate significant differences $(\mathrm{p}<0.05)$ between groups.

Table 4. Blood GSH, MDA, SOD and CAT values in the control $(\mathrm{n}=8)$, local boron $(\mathrm{LB})(\mathrm{n}=8)$, oral boron $(\mathrm{OB})(\mathrm{n}=8)$ and oral + local boron $(\mathrm{OLB})(\mathrm{n}=8)$ groups $($ mean $\pm \mathrm{SD})$

\begin{tabular}{ccccc}
\hline GROUPS & $\begin{array}{c}\text { GSH } \\
(\mathrm{nmol} / \mathrm{ml})\end{array}$ & $\begin{array}{c}\text { MDA } \\
(\mathrm{nmol} / \mathrm{ml})\end{array}$ & $\begin{array}{c}\text { SOD } \\
(\mathrm{U} / \mathrm{mgHb})\end{array}$ & $\begin{array}{c}\text { CATALASE } \\
(\mathrm{k} / \mathrm{mgHb})\end{array}$ \\
\hline Control group & $35,43+4,80$ & $12,25+1,93^{\mathrm{a}}$ & $18,41+2,61^{\mathrm{b}}$ & $762,11+184,33^{\mathrm{b}}$ \\
LB group & $37,94+6,39$ & $9,97+1,73^{\mathrm{ab}}$ & $26,31+6,38^{\mathrm{a}}$ & $1393,33+556,68^{\mathrm{a}}$ \\
OB group & $39,56+6,08$ & $6,87+2,80^{\mathrm{b}}$ & $19,38+1,94^{\mathrm{b}}$ & $849,56+143,24^{\mathrm{b}}$ \\
OLB group & $37,01+4,97$ & $10,69+2,75^{\mathrm{a}}$ & $21,10+5,30^{\mathrm{ab}}$ & $964,93+219,17 \mathrm{ab}$ \\
\hline $\boldsymbol{P}$ & 0,524 & 0,001 & 0,009 & 0,003 \\
\hline
\end{tabular}

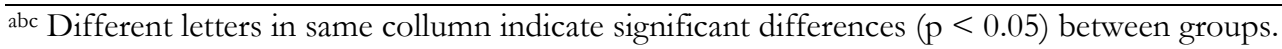

Table 5. Wound tissue GSH, MDA, SOD and CAT values in the control $(\mathrm{n}=8)$, local boron (LB) $(n=8)$, oral boron $(\mathrm{OB})(\mathrm{n}=8)$ and oral + local boron $(\mathrm{OLB})(\mathrm{n}=8)$ groups (mean $\pm \mathrm{SD})$

\begin{tabular}{ccccc}
\hline GROUPS & $\begin{array}{c}\text { GSH } \\
(\mathrm{nmol} / \mathrm{gr} \text { tissue })\end{array}$ & $\begin{array}{c}\text { MDA } \\
(\mathrm{nmol} / \mathrm{gr} \\
\text { tissue })\end{array}$ & $\begin{array}{c}\text { SOD } \\
(\mathrm{U} / \mu \mathrm{g} \\
\text { protein })\end{array}$ & $\begin{array}{c}\text { CATALASE } \\
(k / \mu \mathrm{g} \text { protein })\end{array}$ \\
\hline $\begin{array}{c}\text { Control } \\
\text { group }\end{array}$ & $10,84 \pm 0,52$ & $3,34 \pm 0,28^{\mathrm{a}}$ & $1,68 \pm 0,34^{\mathrm{b}}$ & $0,02 \pm 0,007$ \\
LB group & $10,87 \pm 0,77$ & $3,16 \pm 0,13^{\mathrm{ab}}$ & $3,41 \pm 0,97^{\mathrm{a}}$ & $0,03 \pm 0,01$ \\
OB group & $11,18 \pm 2,56$ & $3,08 \pm 0,15^{\mathrm{b}}$ & $2,53 \pm 0,49^{\mathrm{ab}}$ & $0,02 \pm 0,004$ \\
OLB group & $11,01 \pm 1,42$ & $3,09 \pm 0,17^{\mathrm{b}}$ & $3,41 \pm 0,98^{\mathrm{a}}$ & $0,04 \pm 0,05$ \\
\hline $\boldsymbol{P}$ & 0,848 & 0,044 & 0,0001 & 0,386
\end{tabular}

ab Different letters in same collumn indicate significant differences $(\mathrm{p}<0.05)$ between groups. 


\section{DISCUSSION}

It is emphasized that the administration of 3\% boric acid accelerates especially deep wound healing and reduces two-thirds of the time needed to be spent in intensive care (Blech et al. 1990a). Boron plays an important role in the wound repair process by affecting extracellular matrix synthesis that increases the release of proteoglycans, collagen, and proteins (Benderdour et al. 1997, Benderdour et al. 1998). Demirci et al. (2015) reported that the application of boron-containing hydrogel supports more rapid wound healing by stimulating epithelization, cell migration, and angiogenesis in burn injuries in rats. It has been shown that the application of boroncontaining hydrogel to wounds in diabetic rats contributes to wound healing positively (Demirci et al. 2016). In our study, 3\% boric acid among boron compounds was administered topically to rats, and borax decahydrate was administered per oral at a dose of $10 \mathrm{mg} / \mathrm{kg}$ for 21 days. In LB and OLB groups, wound healing scores, such as reepithelization, granulation tissue formation, collagen formation, inflammatory cell formation, and neovascularization were higher than those in the control and $\mathrm{OB}$ groups. The highest wound healing scores were determined in the OLB group in comparison with other groups. In this study, our results were consistent with above mentioned studies (Benderdour et al. 1998, Nzietchueng et al. 2002, Demirci et al. 2016, Blech et al. 1990b) that the wound healing process by affecting TNF- $\alpha$ release, extracellular matrix synthesis and stimulating angiogenesis and epithelization increased the release of proteoglycans, collagen and proteins.

Demirci et al. (2016) applied boron-containing hydrogel to the wounds formed in diabetic rats and stated that the application of boron-containing hydrogel made wound areas shrink faster on the 8th day of wound healing in comparison with the control group. In another study, it was reported that antioxidant agents vitamin $\mathrm{E}$ and $\alpha$-tocopherol added to the diet in rats made the wound area close more rapidly compared to the control group (Musalmah et al. 2005). Uyar et al. (2017) applied asiatic acid and yarrow cream to the wounds they formed in rats and reported that wound areas shrank more rapidly in both applications in comparison with the control group. In this study, wound areas were observed to shrink faster, especially in LB and OLB groups, than in the control group. In LB group, the wounds were significantly smaller on the 7 th day compared to the control and OLB groups $(p<0.05)$. Furthermore, wound areas were significantly smaller in $\mathrm{LB}, \mathrm{OB}$ and OLB groups on days 7, 9, 11, 13, 17, 19 and 21 than in the control group $(\mathrm{p}<0.05)$. In this respect, it can be said that boron that stands out with its antioxidant properties accelerates wound healing macroscopically.
MDA is one of the most important parameter of lipid peroxidation. It is reported that antioxidant agents, raxofelast and taurine, significantly reduce lipid peroxidation as a direct effective antioxidant and stabilize the plasma membrane as an indirect antioxidant (Değim et al. 2002). Moreover, the addition of $200 \mathrm{mg} / \mathrm{kg}$ vitamin $\mathrm{E}$ and $200 \mathrm{mg} / \mathrm{kg} \alpha$ tocopherol significantly reduces the wound tissue MDA levels in diabetic rats (Musalmah et al. 2005). It is indicated the routine wound application such as asiatic acid and yarrow cream to the wounds reduces wound tissue MDA levels compared to the control group in rats (Uyar et al., 2017). In another study, it has been reported that the application of curcumin, which is an antioxidant agent, significantly reduces MDA levels in wound tissue in rats (Panchatcharam et al. 2006). Korkmaz et al. (2019) stated that intraarticularly administered borax decahydrate reduces the articular cartilage MDA levels with experimentally induced osteochondral defect in rats. Several studies have investigated the effects of boron on some antioxidant or oxidant enzymes in various tissues (such as cartilage tissue, liver, kidney, brain, and heart) (Coban et al. 2015, Ince et al. 2014, Kucukkurt et al. 2015; Korkmaz et al. 2019). However, there have been no reports regarding the effects of boron on wound tissues either topical or oral administrations as well as the wound tissue MDA levels that were significantly lower in OB and OLB groups than control group in this study. These findings are similar to the data with the above mentioned reports. It is suggested that boron positively increases the wound healing process due to inhibition of lipid peroxidation and removing free oxygen radicals causing the tissue damage in wound tissue.

It was reported that the wound tissue GSH levels were lower in the wounds compared to normal skin on days 2, 4, 7 and 14 in rats (Shukla et al. 1997). On the other hand, it was emphasized that wound tissue GSH peroxidase levels were higher in rats treated with curcumin than in the control group. Similarly, Musalmah et al. (2005) reported that vitamin $\mathrm{E}$ and $\alpha$ tocopherol increased wound tissue GSH peroxidase enzyme levels in diabetic rats. It is stated that the intra-articular boron administration increases the cartilage tissue GSH level statistically significantly in the rats with an osteochondral defect (Korkmaz et al. 2019). In this study, it was determined that GSH level was higher especially in the OB and OLB groups than in other groups. In this study, it can be stated that boron probably helps to clean the free oxygen radicals in the damaged tissue, thus preventing the depletion of GSH and as a result helping to maintain the integrity of the cellular membranes in the wound tissue.

SOD and CAT are the basic antioxidant cellular defense system enzymes involved in the elimination of free oxygen radicals from the body and their 
detoxification. CAT also prevents the tissue from highly reactive hydroxyl radicals by decomposing hydrogen peroxide into water and oxygen (Ince et al. 2010). In a study conducted on rats, wound tissue SOD and CAT levels are reported to be lower than those of normal skin tissue (Shukla et al. 1997). It is stated that the administration of vitamin $\mathrm{E}$ in rats increases the wound tissue SOD level (Musalmah et al. 2005), while curcumin application increases both wound tissue SOD and CAT levels (Panchatcharam et al. 2006). Korkmaz et al. (2019), reported that intra-articular boron administration increased the concentration of cartilage tissue SOD and catalase levels more in rats in which they created an osteochondral defect compared to the control group. In the present study, while the lowest wound tissue SOD level was observed in the control group, the highest SOD level was observed in the OLB and LB groups. Moreover, wound tissue CAT levels were determined to be higher in the $\mathrm{LB}, \mathrm{OB}$ and OLB groups in comparison with the control group. In this respect, the fact that boron increases the levels of SOD and catalase that are antioxidant enzymes in the wound tissue shows that these two agents contribute to the antioxidant defense system. This study is the first study that evaluates the effects of orally and topically administered boron on both blood and wound tissue MDA, GSH, SOD and CAT levels in rats.

As a result, it can be said that oral administration of boron in addition to topical treatment contributes the wound healing due to the antioxidant property of boron in wound healing process.

\section{ACKNOWLEDGEMENT}

> This publication was summarized from master thesis entitled "Comparison of the Effects of Orally and LocallyAdministered Boron on Wound Healing and Oxidative Stress in Rats"

$>$ This study was presented at $2^{\text {nd }}$ International Veterinary Surgery Congress of Turkey, 20-23 September 2018, Lefkosa, Cyprus.

$>$ This study was funded by Scientific Research Projects Coordination Unit of Afyon Kocatepe University (Project Number: 16.SAG.BIL.25)

Conflict of Interest: The authors declare that they have no conflict of interest.

\section{REFERENCES}

Aebi HE. Catalase in vitro. In: Bergmeyer HU, editor. Methods of enzymatic enalysis. New York: Academic Press, 1983; pp 673-677.

Beckert S, Königsrainer A, Coerper S. The physiology of wound healing. Therapeutische Umschau. Revue therapeutique, 2007; 64(9): 467-472.

Benderdour M, Hess K, Dzondo-Gadet M, Nabet P, Belleville F, Dousset B. Boron modulates extracellular matrix and TNF $\alpha$ synthesis in human fibroblasts. Biochem. Biophys. Res. Commun. 1998; 246(3):746-751.

Benderdour M, Hess K, Gadet MD, Dousset B, Nabet P, Belleville F. Effect of boric acid solution on cartilage metabolism. Biochem. Biophys. Res. Commun. 1997; 234(1):263-268.

Beutler E, Duron O, Kelly BM. Improved method for the determination of blood glutathione. J. Lab. Clin. Med. 1963; 61(5): 882-8.

Blech MF, Martin C, Borrelly J, Hartemann P. Traitement des plates profondes avec perte de substance; Interet d'une solution d'acide borique $3 \%$. Presse Medicale 1990a; 19:1050-1052.

Blech MF, Martin C, Pichon M, Borrelly J, Hartemann P. Clinical and bacteriologic course of wounds as a function of various protocols of local antisepsis. Rev. Chir. Orthop. 1990b; 76(1): 55-61.

Bolcal C, Yildirim V, Doganci S, Sargin M, Aydin A, Eken A, Ozal E, Kuralay E, Demirkilic U, Tatar H. Protective Effects of Antioxidant Medications on Limb Ischemia Reperfusion Injury. J. Surg. Res. 2007; 139(2): 274-9.

Coban FK, Ince S, Kucukkurt I, Demirel HH, Hazman O. Boron attenuates malathion-induced oxidative stress and acetylcholinesterase inhibition in rats. Drug Chem. Toxicol. 2015;38(4): 391-9.

Değim Z, Çelebi N, Sayan H, Babül A, Erdoğan D, Take G. An investigation on skin wound healing in mice with a taurine-chitosan gel formulation. Amino Acids. 2002; 22:187-198.

Demirci S, Doğan A, Aydın S, Dülger EÇ, Şahin F. Boron promotes streptozotocin-induced diabetic wound healing: roles in cell proliferation and migration, growth factor expression, and inflammation. Mol. Cell. Biochem. 2016; 417(1-2):119-133.

Demirci S, Doğan A, Karakuş E, Halıcı Z, Topçu A, Demirci E, Sahin F. Boron and Poloxamer (F68 and F127) Containing Hydrogel Formulation for Burn Wound Healing. Biol. Trace Elem. Res. 2015; 168:169-80.

Draper HH, Hadley M. Malondialdehyde determination as index of lipid Peroxidation. Methods Enzymol. 1990; 186: 421-31.

Drabkin DL, Austin JH. Spectrophotometric studies. II. Preparations from washed blood cells; nitric oxide, hemoglobin and sulfhemoglobin. J Biol Chem 1935; 112(1):51.

Gultepe EE, Uyarlar C, Bayram İ. Supplementation of Cr Methionine During Dry Period of Dairy Cows and Its Effect on Some Production and Biochemical Parameters During Early Lactation and on Immunity of Their Offspring. Biol. Trace Elem. Res. 2018; 186(1): 143-153.

Luck H. Catalase. In: Bergmeyer HU (ed). Methods in analysis. London: Academy Press. 1955.

Ince S, Keles H, Erdogan M, Hazman O, Kucukkurt I. Protective effect of boric acid against carbon tetrachloride-induced hepatotoxicity in mice. Drug Chem Toxicol. 2012; 35(3): 285-92.

Ince S, Kucukkurt I, Cigerci IH, Fatih Fidan A, Eryavuz A. The effects of dietary boric acid and borax supplementation on lipid peroxidation, antioxidant 
activity, and DNA damage in rats. J. Trace Elem. Med. Biol. 2010; 24(3): 161-4.

Ince S, Kucukkurt I, Demirel HH, Acaroz DA, Akbel E, Cigerci IH. Protective effects of boron on cyclophosphamide induced lipid peroxidation and genotoxicity in rats. Chemosphere. 2014; 108: 197-204.

Murray F. A Comparative Review of the Pharrnacokinetics of Boric Acid in Rodents and Humans. Biol. Trace Elem. Res. 1998; 66:331-41.

Kapan M, Mehmet S, Erdal SAK, Öngören AU. Lokal Fenitoin ve Üre Uygulamasının Yara iyileşmesi Üzerine Olan Etkilerinin Karşılaştırılması. Yeni Tip Dergisi, 2008; 25(4):209-2012.

Keast $\mathbf{D H}$, Orsted $\mathbf{H}$. The basic principles of wound care. Ostomy. Wound. Manage. 1998; 44(8), 24-28.

Korkmaz M, Turkmen R, Demirel HH, Saritas ZK. Effect of Boron on the Repair of Osteochondral Defect and Oxidative Stress in Rats: an Experimental Study. Biol. Trace Elem. Res. 2019; 187(2):425-433.

Kucukkurt I, Ince S, Demirel HH, Turkmen R, Akbel E, Celik Y. The Effects of Boron on Arsenic-Induced Lipid Peroxidation and Antioxidant Status in Male and Female Rats. J. Biochem. Mol. Toxicol. 2015; 29(12):564-71.

Kuru R, Yarat A. Bor ve Sağllğımıza Olan Etkilerine Güncel Bir Bakış. Clin Exp Health Sci 2017; 7:104-114.

Lowry OH, Rosebrough NJ, Farr AL, Randall RJ. Protein measurement with the Folin phenol reagent. J. Biol. Chem. 1951; 193(1):265-75.

Musalmah M, Nizrana MY, Fairuz AH, NoorAini AH, Azian AL, Gapor MT, Wan Ngah WZ. Comparative effects of palm vitamin $\mathrm{E}$ and $\alpha$-tocopherol on healing and wound tissue antioxidant enzyme levels in diabetic rats. Lipids. 2005; 40(6):575-580.

Nzietchueng RM, Dousset B, Franck P, Benderdour M, Nabet P, Hess K. Mechanisms implicated in the effects of boron on wound healing. J. Trace Elem. Med. Biol. 2002; 16(4): 239-244.

Ohkawa H, Ohishi N, Yagi K. Assay for lipid peroxides in animal tissues by thiobarbituric acid reaction. Anal. Biochem. 1979; 95(2):351-8.

Özler M, Şimşek K, Topal T, Öter Ş, Korkmaz A. Pinealektomili ratlarda yara iyileşmesi. Gulhane Med. J. 2010; 52: 181-184.

Panchatcharam M, Miriyala S, Gayathri VS, Suguna L. Curcumin improves wound healing by modulating collagen and decreasing reactive oxygen species. Mol. Cell. Biochem. 2006; 290(1-2): 87-96.

Shukla A, Rasik AM, Patnaik GK. Depletion of reduced glutathione, ascorbic acid, vitamin $\mathrm{E}$ and antioxidant defence enzymes in a healing cutaneous wound. Free Radic. Res. 1997; 26(2): 93-101.

Singh S, Young A, McNaught CE. The physiology of wound healing. Surgery (Oxford), 2017; 35(9): 473-477.

Sun Y, Oberley LW, Li Y. A simple method for clinical assay of superoxide dismutase. Clin. Chem. 1988; 34(3):497-500.

Uçkun Z. Esansiyel bir komponent: bor-borun günlük alımı ve fizyolojik etkileri. J Turkish Sci. Rev. 2013; 6: 119-23.

Uyar A, Akyol T, Yaman T, Keleş ÖF. Ratlarda Deneysel Olarak Oluşturulan Yara Modelinde Civanperçemi (Achillea millefolium) Bitkisinin Yara İyileșmesi ve Oksidatif Stres Üzerine Etkisinin Histopatolojik ve Biyokimyasal Olarak Araştırılması. Van Veterinary
Journal, 2017; 28(3):157-163.

Werner S, Grose R. Regulation of Wound Healing by Growth Factors and Cytokines. Physiol. Rev. 2003;83(3): 835-70.

Wilson JH, Ruszler PL. Long term effects of boron on layer bone strength and production parameters. Br. Poult. Sci. 1998; 39(1): 11-15.

Winterbourn CC, Hawkins RE, Brian M, Carrell RW. The estimation of red cell superoxide dismutase activity. J. Lab. Clin. Med. 1975;85: 337-41. 